\title{
Studying the Moderating Role of Audit Committee Independence in the Relationship between CEO Narcissism and Real Earnings Management
}

\section{Roozbeh Sardari}

Ph.D. Candidate of Accounting, Faculty of Management and Economics, Science and Research Branch, Islamic Azad University, Tehran, Iran. (Email: sardariroozbeh@yahoo.com)

\section{Mohammad Reza Setayesh*}

*Corresponding Author, Assistant prof., Department of Accounting, Faculty of Humanities, Brujerd Branch, Islamic Azad University, Brujerd, Iran. (Email: setayesh_m_r@yahoo.com)

\section{Hamidreza Kordlouie}

Associate prof., Department of Financial Management, Faculty of Management and Accounting, Islamshahr Branch, Islamic Azad University, Islamshahr, Iran. (Email: hamidreza.kordlouie@gmail.com)

\section{Bahman Banimahd}

Associate prof., Department of Accounting, Faculty of Management and Accounting, Karaj Branch, Islamic Azad University, Karaj, Iran. (Email: b_banimahd@yahoo.com)

Document Type: Original Article

Received: 2020/09/07
2021, Vol. 5, No. 3. 58-77.

Published: 2021/10/05

\begin{abstract}
A manager's personality and psychological attributes may influence his or her performance, thereby affecting the quality of financial reporting by companies. On the one hand, today there is an increasing requirement for protecting the interests of investors as providers of investment and the most important group of accounting information and financial report users. The development of audit committees is among the mechanisms expected to be effective in protecting the interests of different groups of accounting information and financial report
\end{abstract}


users. In order to act effectively, an audit committee must be independent. Therefore, the present study aims to examine the role played by the independence of audit committee members as a quality of an audit committee to identify how it may moderate the relationship between managers' narcissism and real earnings management in the firms listed in the Tehran Stock Exchange (TSE) using a statistical sample consisting of 642 observations (year-firm) over the period 2013-2018. The findings obtained through hypothesis testing using statistical analysis of panel data suggest that independence of audit committee members does not moderate the relationship between CEO's narcissism and real earnings management through abnormal cash flow, real earnings management through abnormal production, and real earnings management through abnormal discretionary expenses. Thus, the independence of audit committee members as a moderator cannot moderate the relationship between CEO's narcissism and real earnings management.

Keywords: Audit committee independence, CEO narcissism, Real earnings management

DOI: 10.30699/IJF.2021.247085.1155

Publisher: Iran Finance Association Copyright: author(s)

Type of License: Creative Commons License (CC-BY 4.0)

\section{Introduction}

CEOs play a key role in intra-organizational leadership and direction while presenting the organization to the outside world. Unfortunately, the growing number of scandals caused by misconduct on the part of managers has eroded the trust in top managers. Such misconducts have been examined from sociological, psychological, economic, and criminological points of view. Terms like white-collar crimes, fraud, and organizational deviation have been frequently used in the literature to describe misconduct by managers. Research has not sufficiently explored many causes and consequences of unethical activities among top managers. One managerial misconduct with irreversible consequences for companies concerns earnings management. Most studies conducted so far to explain factors influencing earnings management have focused on particular qualities of companies while recent studies suggest managers' personality traits as important factors contributing to income smoothing (Bouwman, 2014). Given the dearth of research in this area, the present study is an important one in that it examines whether a monitoring system established at a firm can or cannot reduce the effects of managerial misconduct on the quality of financial statements. Therefore, the main question 
posed here is how audit committee independence, as a quality of an audit committee, may influence the link between CEO narcissism and real earnings management (REM). The objective here is to help investors and shareholders learn about what they should do to remove the effects of managerial misconduct on a firm's financial information (as linked to a CEO's personal qualities). In addition, our findings can inform the decisions made by the securities and exchange organization (as the regulating authority of the capital market) towards legislation intended to improve corporate governance at listed companies. These findings can also be treated as a basis for developing a theoretical framework for financial behavioral and corporate governance and used to put forth new ideas in these areas.

\section{Research Background}

The past few years have witnessed an increasing formation and development of audit committees in underdeveloped countries due to growing international operations, intensified activities of corporations that compete over competitive advantages, higher levels of liabilities arising out of environmental damage, role and influence of managerial estimations in figures reported on financial statements and reports, absence of a valid basis to help independent auditors verify what managers claim about the adequacy of their internal control structures, growing application of the computerized system, and consequently greater challenges in monitoring how these systems are controlled (Rahimian, 2003). Development of audit committees among the mechanisms expected to be effective in protecting the interests of different groups of accounting information and financial report users. Audit committees will continue to play a key role in enhancing the desirability of presenting financial reports and in filling the gap caused by the lack of a validation mechanism for these reports. On the other hand, companies and their shareholders rely on the judgments made by audit committee members for closer monitoring of risks, preventing wasted resources, complying with regulations and legal requirements (Tariverdi \& Ghaderi, 2018). Through constant monitoring, an audit committee will ensure that a manager moves towards the achievement of corporate goals while making his or her best to secure the company's interests, thereby enhancing the firm's performance. This will in turn lead to improved quality of financial reports, more transparent information, and lower investment risks. According to the Public Oversight Board (1994), Blue Ribbon Committee (1999), the National Association of Corporate Directors (1999), and Coopers (2000), the performance of an audit committee will be of a high quality when 
its members are independent, and this will, in turn, gives a higher validity to financial reporting. Persons (2005) noted that an audit committee member is called an independent member if he or she is not personally or financially liked to a corporation or its CEOs. In addition, Persons believes that frauds become less likely when an audit committee is independent. According to Article 5, the Audit Committee Charter passed by the Security and Exchange Organizations, an audit committee consists of three to five members with the majority of them being independent and selected and appointed by the board of directors. In addition, the committee chairperson must be an independent or a financially non-executive board member.

The term "non-executive" member of an audit committee refers to those members who, while being a board member, do not assume an executive or operational role. Appointing external members can give the committee members a higher level of independence. In other words, when executive directors are not present at an audit committee, the auditors can more explicitly discuss such issues as weaknesses of internal controls, disagreements with managers on accounting principles and practices, potential signs of managerial misconducts or other illegal acts of those in charge at the company. In this way, an audit committee can improve effectiveness and productivity in financial conditions by controlling managerial measures. Meanwhile, narcissism is a personality and psychological dimension of management defined under relatively stable individual differences which include inflated self-view, hubristic pride, and self-aggrandizement (Campbell et al., 2007). Those with high narcissism scores on personality tests are relatively domineering, pretentious, self-centered, and extremist individuals, and these characteristics are very likely to push highly narcissistic managers toward fraudulent actions. Narcissist CEOs tend to take unethical actions to achieve their goals. They also need attention, encouragement, and admiration from others (Wallace \& Baumeister, 2002). To this end, they may act in ways that attract public attention. Earning an announcement can serve as a good means for managers to demonstrate their capabilities (Amernic \& Craig, 2010).

On the other hand, previous studies have examined the connection between corporate governance components and the personality attributes of directors. Salter (2008) showed that through their misconduct, narcissist executives or board members reduce the effectiveness of corporate governance principles within an organization. Duellman et al. (2005) demonstrated that a strong audit committee lowers the willingness of overconfident directors to employ a lowquality auditor. Therefore, a powerful corporate governance system is expected to reduce fraudulent actions among directors, thereby enhancing the quality of 
financial information provided by corporations.

\section{Literature Review}

Zebedee et al. (2018) studied the link between CEO narcissism and the tone of earnings announcements. They showed that narcissist managers use more positive, optimistic words in announcing earnings (reporting their activities). They also found that these positive words drop in frequency as narcissist managers get older.

In a study using the data on 500 US firms, Ham et al. (2017) found that CEO narcissism is linked to overinvestment in research and development and merger of companies. They did not found a relationship between CEO narcissism and capital expenditures. They also showed that companies run by narcissist CEOs have lower levels of efficiency and operating cash flow.

Capalbo et al. (2017) examined the relationship between CEO narcissism and earnings management. Their study demonstrated a connection between these two variables.

Kibiya et al. (2016) examined the connection between independence and proficiency of audit committee members, ownership, and quality of financial reporting. They found that oversight by an audit committee influences the quality of financial reporting.

Al-Rassas and Kamardin (2016) pointed out that the independence of audit committee members is linked to the quality of earnings. Frino et al. (2015) noted that the emergence of narcissism among managers involves activities that lead to earnings management.

Hassan and Ibrahim (2014) found a negative significant relationship between REM and the independence of audit committee members.

Sun et al. (2014) examined how REM is connected to the independence of audit committee members. Their samples consisted of US companies that attempted REM. They found a positive relationship between the independence of audit committee members and REM measured through abnormal cash flows.

In a study on CEO narcissism and accounting, Olsen et al. (2014) examined 1,118 observations during 2000-2009 to find out a direct significant relationship between CEO narcissism and dividends and share prices as two key factors involved in financial performance, since narcissist managers try to present a more impressive financial performance by reporting higher earnings on shares through manipulating operating and real activities more than they manipulate accruals. They also found that narcissist managers prefer real 
activities over accruals in managing earnings.

Hales et al. (2011) found a direct link between narcissist managers and aggressive financial reporting.

Alves et al. (2011) found a significant relationship between the presence of an audit committee and earnings management.

Krishnamoorthy et al. (2002) demonstrated that the independence of an audit committee is an effective factor influencing the efficiency of the committee.

Fakhari and Rezaei (2018) found a positive significant connection between the existence of an audit committee and a firm's information environment. In other words, when an audit committee is established within companies, their information environment becomes more transparent with an increase in the information environment index.

Kordlouei andYousefi (2017) examined the quality of financial statements and audit committee characteristics. Their findings suggested that these characteristics enhance the quality of financial statements.

In a study on the link between audit committees, earnings management, and cash flow management, Hassas Yeganeh et al. (2017) found that the presence of an audit committee was not significantly related to earnings management and cash flow management.

In a study on the connection between CEO narcissism and earnings management through discretionary accruals and a firm's financial performance, Khajavi et al. (2016) found that CEO narcissism had a positive significant impact on discretionary income and discretionary accruals as two criteria for earnings management. In addition, it was observed that increased CEO narcissism resulted in a corresponding increase in financial performance with a slight slope.

Nayeri et al. (2015) used systematic elimination to examine the link between internal audit, audit committee, and earnings management in a sample of companies listed in the Tehran Stock Exchange (TSE) for the period 20012011. Their findings indicated a significant inverse relationship between earnings management and internal audit while no connection was observed between the audit committee and earnings management.

Soleimani Amiri and Fasihi (2015) examined how REM and accrual management is linked to independence, level of expertise, and size of the audit committee. Their findings demonstrated a significant negative relationship 
between the independence of the audit committees and accrual-based earnings management while other characteristics of audit committees were not found to have a significant relationship to accrual-based earnings management. A closer examination of the link between the size of the audit committee and REM revealed that only the level of financial expertise of audit committee members was significantly related to REM.

Bolo and Hasni Al-Qar (2015) studied how managerial overconfidence influenced income smoothing in TSE-listed firms. To measure overconfidence, they used two criteria based on investment decisions. In addition, they used the ratio of the standard deviation of operating profit to the standard deviation of operating cash flow as a measure of income smoothing. They found that managerial overconfidence increases income smoothing.

\section{Research Hypotheses}

H1: There is a significant positive relationship between CEO narcissism and abnormal operating cash flow.

$\mathrm{H} 2$ : There is a significant positive relationship between CEO narcissism and abnormal production costs.

H3: There is a significant positive relationship between CEO narcissism and abnormal discretionary expenses.

H4: The independence of audit committee members plays an important role in moderating the impact of CEO narcissism on abnormal operating cash flow.

H5: The independence of audit committee members plays an important role in moderating the impact of CEO narcissism on abnormal production costs.

H6: The independence of audit committee members plays an important role in moderating the impact of CEO narcissism on abnormal discretionary expenses.

\section{Methodology}

The statistical population of the present study consists of all active TSE-listed firms that provide financial information. The study covered a period of 6 years from 2013 to 2018. A sample was selected using the systematic elimination (screening) method. The following conditions were applied as inclusion criteria to include a sample of 107 companies in the study. A company was included in the study if 
- Its fiscal year ended on March 19 (to make it easier to compare the firms);

- It has not changed its fiscal year or stopped its operations during the period studied;

- Had its complete financial information, financial statements, and notes to these statements available on the security exchange market website for the period studied;

- Was not among the companies operating in the financial industry, including investment, banking, leasing, insurance, and financial institutions; and

- Its audit committee had been established in or before 2013 .

A causal-ex post facto design was used in a descriptive methodology based on a regression analysis where data were combined and integrated. The data were collected from Tadbir Pardaz compact disc and the Codal website. The data were then analyzed using Eviews.

\section{Model}

The research hypotheses are tested using the following models:

$\operatorname{REM}(\mathrm{CFO})_{\text {it }}=\beta_{0}+\beta_{1}$ NARCS $_{\text {it }}$

$+\sum \beta 2 \mathrm{LEV}_{\mathrm{it}}+\sum \beta 3 \mathrm{SIZE}_{\mathrm{it}}+\sum \beta 4 \mathrm{MTB}_{\mathrm{it}}+\sum \beta 5 \mathrm{TENURE}_{\mathrm{it}}+\varepsilon_{\mathrm{it}}$

REM(Prod. Costs) ${ }_{i t}=\beta_{0}+\beta_{1}$ NARCS $_{i t}+\sum \beta 2 L V_{i t}+\sum \beta 3$ SIZE $_{i t}+$

$\sum \beta 4 \mathrm{MTB}_{\mathrm{it}}+\sum \beta 5 \mathrm{TENURE}_{\mathrm{it}}+\varepsilon_{\mathrm{it}}$

$\operatorname{REM}\left(\right.$ Disc. EXP) ${ }_{\mathrm{it}}=\beta_{0}+\beta_{1} \mathrm{NARCS}_{\mathrm{it}}+\sum \beta 2 \mathrm{LEV}_{\mathrm{it}}+\sum \beta 3 \mathrm{SIZE}_{\mathrm{it}}+$

$\sum \beta 4 \mathrm{MTB}_{\mathrm{it}}+\sum \beta 5 \mathrm{TENURE}_{\mathrm{it}}+\varepsilon_{\mathrm{it}}$

REM(CFO) $)_{i t}=\beta_{0}+\beta_{1}$ NARCS $_{i t}+\beta 2$ ACIND $_{i t}+\beta_{3}$ NARCS $_{i t} *$ ACIND $_{i t}+$ $\sum \beta 4 \mathrm{LEV}_{\mathrm{it}}+\sum \beta 5 \mathrm{SIZE}_{\mathrm{it}}+\sum \beta 6 \mathrm{MTB}_{\mathrm{it}}+\sum \beta 7 \mathrm{TENURE}_{\mathrm{it}}+\varepsilon_{\mathrm{it}}$

REM(Prod. Costs) ${ }_{\text {it }}=\beta_{0}+\beta_{1}$ NARCS $_{\text {it }}+\beta 2$ ACIND $_{\text {it }}+\beta_{3}$ NARCS $_{\text {it }} *$

$\mathrm{ACIND}_{\mathrm{it}}+\sum \beta 4 \mathrm{LEV}_{\mathrm{it}}+\sum \beta 5 \mathrm{SIZE}_{\mathrm{it}}+\sum \beta 6 \mathrm{MTB}_{\mathrm{it}}+\sum \beta 7 \mathrm{TENURE}_{\mathrm{it}}+\varepsilon_{\mathrm{it}}$

REM(Disc. EXP) ${ }_{\text {it }}=\beta_{0}+\beta_{1}$ NARCS $_{\text {it }}+\beta 2$ ACIND $_{i t}+\beta_{3}$ NARCS $_{\text {it }} *$

$\mathrm{ACIND}_{\mathrm{it}}+\sum \beta 4 \mathrm{LEV}_{\mathrm{it}}+\sum \beta 5 \mathrm{SIZE}_{\mathrm{it}}+\sum \beta 6 \mathrm{MTB}_{\mathrm{it}}+\sum \beta 7 \mathrm{TENURE}_{\mathrm{it}}+\varepsilon_{\mathrm{it}}$

\section{Measuring variables}

Real earnings management

As a variable, REM consists of abnormal operating cash flow (REM (CFO)), 
abnormal production (REM(Prod. Costs)), and abnormal discretionary expenses (REM(Disc. EXP)). Consistent with Roychoudhuri (2006), Yu (2008), Xang (2008) and Fakhari and Adili (2012), the following models were used respectively to estimate abnormal cash flows, abnormal production costs, and abnormal discretionary expenses, where the residuals of the models were used as a measure of earnings management through REM:

\section{A: abnormal operating cash flow:}

$C F O_{i t} / A_{i t-1}=\alpha_{0}+\alpha_{1} / A_{i t-1}+\beta_{1}\left(\mathrm{~S}_{i t} / \mathrm{A}_{\mathrm{it}-1}\right)+\beta_{2}\left(\Delta \mathrm{S}_{i t} / \mathrm{A}_{\mathrm{it}-1}\right)+\varepsilon_{i t}$

where CFOit represents operating cash flow, Ait-1 is the total opening assets at the beginning of the period, Sit denotes sales, $\Delta$ Sit is sales variations, and cit shows error (abnormal operating cash flow).

\section{B: abnormal production costs:}

$P R O D_{i t} / A_{i t-1}=\alpha_{0}+\alpha_{1} / A_{i t-1}+\beta_{1}\left(\mathrm{~S}_{i t} / \mathrm{A}_{\mathrm{it}-1}\right)+\beta_{2}\left(\Delta \mathrm{S}_{i t} / \mathrm{A}_{\mathrm{t}-1}\right)+\beta_{3}\left(\Delta \mathrm{S}_{i t-1} / \mathrm{A}_{\mathrm{it}-1}\right)+\varepsilon_{i t}$

PROD ${ }_{\text {it: }}$ cost of goods sold

$\varepsilon_{\mathrm{it}}:$ error (abnormal production cost)

\section{C: abnormal discretionary expenses:}

$\operatorname{DISEXP}_{i t} / A_{i t-1}=\alpha_{0}+\alpha_{1} / A_{i t-1}+\beta_{1}\left(\mathrm{~S}_{i t} / \mathrm{A}_{\mathrm{it}-1}\right)+\varepsilon_{i t}$

DISEXPit: total distribution, general, and sales expenses

$\varepsilon_{\mathrm{it}}$ : error (abnormal discretionary expenses)

NARCS represents CEO narcissism. Similar to Charles Ham et al. (2017), in this study the size of the CEO's signature on annual financial statements was used as a measure of CEO narcissism. First, a rectangle was drawn around the signature where each side of the rectangle touched the most extreme endpoint of the signature. Then, the area of the rectangle was measured by multiplying the length and width (in centimeters) of the rectangle to determine the size of the signature.

ACIND denotes the independence of audit committee members. Here, independence was measured using the ratio of independent or non-executive committee members to the total committee members at the company $i$ in the year $\mathrm{t}$. 
Other variables:

SIZE $_{\mathrm{it}}$ : the size of the company which is equal to the logarithm of the market value of equity

$\mathrm{LEV}_{\mathrm{it}}$ : financial leverage which is total liabilities divided by total assets

TENURE $_{\mathrm{it}}$ : the number of years a CEO has been holding his position

$\mathrm{MTB}_{\mathrm{it}}$ : ratio of the market value of a company (yearend closing share price at the stock exchange) to its book value

\section{Research findings}

\section{Descriptive statistics}

Exhibit 1 presents the descriptive statistics for the study variables. These statistics contain information on central tendency (mean and median) and dispersion (standard deviation, skewness, kurtosis, and max and min) parameters for the variables.

As shown in this table, CEO narcissism has the greatest dispersion ( $\mathrm{SD}=$ 3.95) with the smallest dispersion belonging to REM through abnormal discretionary expenses $(\mathrm{SD}=0.02)$.

The evidence obtained in the study showed that REM through abnormal cash flow, REM through abnormal discretionary expenses, CEO narcissism, tenure, audit committee independence, and market-book value ratio were positively skewed while other study variables were negatively skewed. In addition, all variables had positive kurtosis.

Table 1. Descriptive statistics for study variables

\begin{tabular}{|c|c|c|c|c|c|c|c|}
\hline & Min. & Max. & Mean & SD & Median & Skewness & kurtosis \\
\hline $\begin{array}{c}\text { REM through abnormal } \\
\text { cash flow }\end{array}$ & -0.16 & 0.17 & 0.00 & 0.09 & 0.00 & 0.11 & 2.34 \\
\hline $\begin{array}{c}\text { REM through abnormal } \\
\text { production }\end{array}$ & -0.21 & 0.17 & 0.00 & 0.10 & 0.00 & -0.33 & 2.78 \\
\hline $\begin{array}{c}\text { REM through abnormal } \\
\text { discretionary expenses }\end{array}$ & -0.04 & 0.04 & 0.00 & 0.02 & 0.00 & 0.52 & 2.98 \\
\hline $\begin{array}{c}\text { CEO narcissism (signature } \\
\text { size) }\end{array}$ & 0.50 & 18.00 & 6.20 & 3.35 & 5.50 & 1.03 & 3.95 \\
\hline $\begin{array}{c}\text { Independence of audit } \\
\text { committee members }\end{array}$ & 0.67 & 1.00 & 0.97 & 0.09 & 1.00 & -3.14 & 11.05 \\
\hline Company size & 4.9 & 8.66 & 6.35 & 0.67 & 6.26 & 0.95 & 3.8 \\
\hline Leverage & 0.23 & 0.88 & 0.57 & 0.18 & 0.58 & -0.20 & 2.18 \\
\hline Tenure & 1.00 & 7.00 & 2.79 & 1.87 & 2.00 & 0.95 & 2.80 \\
\hline market-to-book ratio & 0.81 & 6.47 & 2.96 & 1.59 & 2.62 & 0.72 & 2.62 \\
\hline Number of observations & & \multicolumn{7}{|c|}{642} & & \\
\hline
\end{tabular}




\section{Inferential statistics}

\section{Limmer F-test}

Prior to testing the research hypotheses, an F-test was run to decide on using a fixed-effects model (pooled data) or non-fixed-effects model (panel data) on the integrated data.

Table 2. F-test results

\begin{tabular}{|c|c|c|c|c|}
\hline Null hypothesis & $\begin{array}{c}\text { Test } \\
\text { model }\end{array}$ & Dependent variable & Statistic & Significance level \\
\hline \multirow{6}{*}{$\begin{array}{l}\text { The intercept is } \\
\text { the same for all } \\
\text { cross-sections }\end{array}$} & H1 & $\begin{array}{l}\text { REM through abnormal } \\
\text { cash flow }\end{array}$ & 1.325865 & 0.0247 \\
\hline & $\mathrm{H} 2$ & $\begin{array}{l}\text { REM through abnormal } \\
\text { production }\end{array}$ & 3.915027 & 0 \\
\hline & H3 & $\begin{array}{l}\text { REM through abnormal } \\
\text { discretionary expenses }\end{array}$ & 3.938083 & 0 \\
\hline & $\mathrm{H} 4$ & $\begin{array}{l}\text { REM through abnormal } \\
\text { cash flow }\end{array}$ & 1.302506 & 0.033 \\
\hline & H5 & $\begin{array}{l}\text { REM through abnormal } \\
\text { production }\end{array}$ & 5.298626 & 0 \\
\hline & H6 & $\begin{array}{l}\text { REM through abnormal } \\
\text { discretionary expenses }\end{array}$ & 3.892664 & 0 \\
\hline
\end{tabular}

Given the level of significance in the F-test, intercepts are not identical for all cross-sections and therefore panel data are preferred for testing the research hypothesis.

\section{Hausman test}

Once panel data were selected through F-test, the Hausman test was run to determine whether a fixed or random-effects model should be used.

Table 3. Hausman test results

\begin{tabular}{|c|c|c|c|c|c|}
\hline Null hypothesis & $\begin{array}{c}\text { Test } \\
\text { model }\end{array}$ & $\begin{array}{c}\text { Dependent } \\
\text { variable }\end{array}$ & Statistic & $\begin{array}{c}\text { Significan } \\
\text { ce level }\end{array}$ & Result \\
\hline & $\mathrm{H} 1$ & $\begin{array}{c}\text { REM through } \\
\text { abnormal cash flow }\end{array}$ & 4.265749 & 0.5118 & $\begin{array}{c}\text { Confirmed } \\
\text { (random } \\
\text { effects) }\end{array}$ \\
\cline { 2 - 6 } The differences \\
$\begin{array}{c}\text { in coefficients are } \\
\text { not systematic. }\end{array}$ & $\mathrm{H} 2$ & $\begin{array}{c}\text { REM through } \\
\text { abnormal } \\
\text { production }\end{array}$ & $\begin{array}{c}14.28009 \\
7\end{array}$ & 0.0139 & $\begin{array}{c}\text { Rejected } \\
\text { (fixed effects) }\end{array}$ \\
\cline { 2 - 6 } & $\mathrm{H} 3$ & $\begin{array}{c}\text { REM through } \\
\text { abnormal } \\
\text { discretionary } \\
\text { expenses }\end{array}$ & 6.063238 & 0.3001 & $\begin{array}{c}\text { Confirmed } \\
\text { (random } \\
\text { effects) }\end{array}$ \\
\hline
\end{tabular}


Studying the Moderating Role of Audit Committee Independence...

\begin{tabular}{|c|c|c|c|c|c|}
\hline & H4 & $\begin{array}{c}\text { REM through } \\
\text { abnormal cash flow }\end{array}$ & 5.272923 & 0.6267 & $\begin{array}{c}\text { Confirmed } \\
\text { (random } \\
\text { effects) }\end{array}$ \\
\cline { 2 - 6 } & H5 & $\begin{array}{c}\text { REM through } \\
\text { abnormal } \\
\text { production }\end{array}$ & $\begin{array}{c}14.55197 \\
3\end{array}$ & 0.0422 & $\begin{array}{c}\text { Rejected } \\
\text { (fixed effects) }\end{array}$ \\
\cline { 2 - 6 } & $\begin{array}{c}\text { REM through } \\
\text { abnormal } \\
\text { discretionary } \\
\text { expenses }\end{array}$ & 7.249982 & 0.4033 & $\begin{array}{c}\text { Confirmed } \\
\text { (random } \\
\text { effects) }\end{array}$ \\
\hline
\end{tabular}

Given the significance levels obtained from the Hausman test, the table presents the application of fixed and random effects.

\section{Collinearity test for study variables}

Collinearity indicates a linear relationship between explanatory or independent variables. One way to identify whether or not collinearity exists is to examine the correlation between study variables. If correlations between independent variables are not strong, there will be no collinearity problem. Variance inflation factor (VIF) was used here to examine collinearity between the study variables. Exhibit 4 presents the output that indicates the presence or absence of collinearity among the variables.

Table 4. Collinearity between the variables

\begin{tabular}{|c|c|}
\hline Variable & VIF \\
\hline NARCS & 8.015521 \\
\hline NARCS*ACIND & 8.080829 \\
\hline ACIND & 1.233675 \\
\hline SIZE & 1.06791 \\
\hline LEV & 1.053012 \\
\hline TENURE & 1.020799 \\
\hline MTB & 1.066352 \\
\hline
\end{tabular}

As seen in the table above, VIF values are smaller than 10 , indicating that there are no multiple correlations (multicollinearity) between the independent variables.

\section{Testing constant variance for error terms}

Constant variance for error terms is tested to determine heteroscedasticity. The null and alternative hypotheses are as described below: 
$\mathrm{H}_{0}$ : Variance of the error term (residuals) is constant (error terms are homoscedastic).

$\mathrm{H}_{1}$ : Variance of the error term (residuals) is not constant (error terms are heteroscedastic).

Table 5. heteroscedasticity/ homoscedasticity test for error terms

\begin{tabular}{|c|c|c|c|}
\hline $\begin{array}{c}\text { Test } \\
\text { Model }\end{array}$ & Dependent variable & Statistic & Significance level \\
\hline H1 & REM through abnormal cash flow & 1.701722 & 0.1321 \\
\hline H2 & REM through abnormal production & 1.352477 & 0.2405 \\
\hline H3 & $\begin{array}{c}\text { REM through abnormal discretionary } \\
\text { expenses }\end{array}$ & 1.843667 & 0.1023 \\
\hline H4 & REM through abnormal cash flow & 1.352262 & 0.2231 \\
\hline H5 & REM through abnormal production & 0.993388 & 0.4348 \\
\hline H6 & $\begin{array}{c}\text { REM through abnormal discretionary } \\
\text { expenses }\end{array}$ & 1.528507 & 0.1545 \\
\hline
\end{tabular}

As seen in the table above, the significance levels for the heteroscedasticity/ homoscedasticity test for error terms (residuals) are below 5\% and therefore the null hypothesis (constant variance for residuals) is confirmed.

Table 6. Model fit for $\mathrm{H} 1$

\begin{tabular}{|c|c|c|c|}
\hline Variable & $\begin{array}{c}\text { Coefficient of the explanatory } \\
\text { variable }\end{array}$ & SD & p-value \\
\hline NARCS & -0.000731 & 0.000984 & 0.4579 \\
\hline SIZE & 0.006883 & 0.005282 & 0.1930 \\
\hline LEV & -0.088922 & 0.019092 & 0 \\
\hline TENURE & -0.001162 & 0.001730 & 0.5018 \\
\hline MTB & 0.006857 & 0.002037 & 0.0008 \\
\hline Constant & 0.001698 & 0.038341 & 0.9647 \\
\hline Coefficient of determination & 0.052084 & \\
\hline $\begin{array}{c}\text { The adjusted coefficient of } \\
\text { determination }\end{array}$ & 0.044631 \\
\hline F-statistic & 6.989052 \\
\hline Probability of F-statistic & 0.000002 \\
\hline Durbin-Watson statistic & 1.968596 \\
\hline
\end{tabular}

The results presented in Exhibit 6 indicate a negative relationship between CEO narcissism and REM through abnormal cash flow, which is insignificant given the respective p-value that is above the threshold of $5 \%$. In other words, there is no significant relationship between CEO narcissism and REM through abnormal cash flow. 
Table 7. Model fit for $\mathrm{H} 2$

\begin{tabular}{|c|c|c|c|}
\hline Variable & $\begin{array}{c}\text { Coefficient of the explanatory } \\
\text { variable }\end{array}$ & SD & p-value \\
\hline NARCS & 0.000238 & 0.001276 & 0.8522 \\
\hline SIZE & -0.023463 & 0.016914 & 0.1660 \\
\hline LEV & 0.067909 & 0.037184 & 0.0684 \\
\hline TENURE & 0.004453 & 0.001979 & 0.0248 \\
\hline MTB & -0.001633 & 0.002422 & 0.9897 \\
\hline Constant & 0.109098 & 0.115538 & 0.3455 \\
\hline Coefficient of determination & 0.480909 & \\
\hline $\begin{array}{c}\text { The adjusted coefficient of } \\
\text { determination }\end{array}$ & 0.372194 \\
\hline F-statistic & 4.423561 \\
\hline Probability of F-statistic & 0 \\
\hline Durbin-Watson statistic & 1.691989 \\
\hline
\end{tabular}

The results presented in Exhibit 7 indicate a positive relationship between CEO narcissism and REM through abnormal production. However, given the p-value which is above the 5\% threshold, this relationship is not statistically significant. In other words, there is no significant relationship between CEO narcissism and REM through abnormal production.

Table 8. Model fit for $\mathrm{H} 3$

\begin{tabular}{|c|c|c|c|}
\hline Variable & $\begin{array}{c}\text { Coefficient of the explanatory } \\
\text { variable }\end{array}$ & SD & p-value \\
\hline NARCS & -0.000613 & 0.000215 & 0.0044 \\
\hline SIZE & 0.001293 & 0.001473 & 0.3804 \\
\hline LEV & -0.005602 & 0.004764 & 0.2401 \\
\hline TENURE & -0.000842 & 0.000355 & 0.0178 \\
\hline MTB & -0.000537 & 0.000410 & 0.1908 \\
\hline Constant & -0.001292 & 0.010427 & 0.9014 \\
\hline Coefficient of determination & 0.026434 & \\
\hline $\begin{array}{c}\text { The adjusted coefficient of } \\
\text { determination }\end{array}$ & 0.018780 \\
\hline F-statistic & 3.453665 \\
\hline Probability of F-statistic & 0.004354 \\
\hline Durbin-Watson statistic & 1.641604 \\
\hline
\end{tabular}

The results presented in Exhibit 8 shows a negative relationship between CEO narcissism and REM through abnormal discretionary expenses. The relationship is significant, given the p-value which is below the 5\% threshold. In other words, there is a statistically significant relationship between CEO narcissism and REM through abnormal discretionary expenses. 
Iranian Journal of Finance, 2021, Vol. 5, No. 3 (Sardari, R.)

Table 9. Model fit for $\mathrm{H} 4$

\begin{tabular}{|c|c|c|c|}
\hline Variable & $\begin{array}{c}\text { Coefficient of the explanatory } \\
\text { variable }\end{array}$ & SD & p-value \\
\hline NARCS & -0.003438 & 0.002732 & 0.2087 \\
\hline NARCS*ACIND & 0.038151 & 0.036907 & 0.3017 \\
\hline ACIND & -0.064161 & 0.040527 & 0.1139 \\
\hline SIZE & 0.007483 & 0.005305 & 0.1589 \\
\hline LEV & -0.088398 & 0.019120 & 0 \\
\hline TENURE & -0.001093 & 0.001730 & 0.5280 \\
\hline MTB & 0.006650 & 0.002042 & 0.0012 \\
\hline Constant & 0.050033 & 0.052132 & 0.3376 \\
\hline Coefficient of determination & \multicolumn{3}{|c}{0.056079} \\
\hline The adjusted coefficient of & 0.045657 \\
\hline determination & \multicolumn{3}{|c}{0.380922} \\
\hline F-statistic & \multicolumn{3}{|c}{} \\
\hline Probability of F-statistic & \multicolumn{3}{|c|}{} \\
\hline Durbin-Watson statistic & \multicolumn{3}{|c}{} \\
\hline
\end{tabular}

The results depicted in Exhibit 9 show that there is a positive relationship between CEO narcissism as a moderator in the independence of audit committee members (NARCS*ACIND) and REM through abnormal cash flow. This relationship is statistically insignificant because the p-value is above the 5\% threshold. In other words, the independence of audit committee members does not moderate the relationship between CEO narcissism and REM through abnormal cash flow.

Exhibit 10. Model fit for H5

\begin{tabular}{|c|c|c|c|}
\hline Variable & $\begin{array}{l}\text { Coefficient of the explanatory } \\
\text { variable }\end{array}$ & SD & p-value \\
\hline NARCS & 0.001779 & 0.003358 & 0.5964 \\
\hline NARCS* ACIND & -0.021338 & 0.042898 & 0.6191 \\
\hline ACIND & 0.017669 & 0.044335 & 0.6904 \\
\hline SIZE & -0.023135 & 0.017015 & 0.1745 \\
\hline LEV & 0.067964 & 0.037421 & 0.0699 \\
\hline TENURE & 0.004561 & 0.001993 & 0.0225 \\
\hline MTB & -0.00168 & 0.002433 & 0.9713 \\
\hline Constant & 0.095322 & 0.126117 & 0.4501 \\
\hline Coefficient of determination & \multicolumn{3}{|c|}{0.481183} \\
\hline $\begin{array}{c}\text { The adjusted coefficient of } \\
\text { determination }\end{array}$ & \multicolumn{3}{|c|}{0.370149} \\
\hline F-statistic & \multicolumn{3}{|c|}{4.333633} \\
\hline Probability of F-statistic & \multicolumn{3}{|l|}{0} \\
\hline Durbin-Watson statistic & \multicolumn{3}{|c|}{1.694512} \\
\hline
\end{tabular}


The results presented in Exhibit 10 shows that there is a negative relationship between CEO narcissism as a moderator in the independence of committee members (NARCS*ACIND) and REM through abnormal production. This relationship is not statistically significant because the respective p-value is above the 5\% threshold. In other words, the independence of audit committee members does not moderate the relationship between CEO narcissism and REM through abnormal production.

Exhibit 11. Model fit for H6

\begin{tabular}{|c|c|c|c|}
\hline Variable & $\begin{array}{c}\text { Coefficient of the explanatory } \\
\text { variable }\end{array}$ & SD & p-value \\
\hline NARCS & -0.000869 & 0.000578 & 0.1330 \\
\hline NARCS* ACIND & 0.003729 & 0.007592 & 0.6235 \\
\hline ACIND & 0.007981 & 0.008066 & 0.3229 \\
\hline SIZE & 0.001353 & 0.001478 & 0.3603 \\
\hline LEV & -0.005576 & 0.004771 & 0.2430 \\
\hline TENURE & -0.000854 & 0.000355 & 0.0166 \\
\hline MTB & -0.000545 & 0.000410 & 0.1842 \\
\hline Constant & -0.010478 & 0.012673 & 0.4083 \\
\hline Coefficient of determination & 0.029649 & \\
\hline The adjusted coefficient of \\
determination
\end{tabular}

The results shown on Exhibit 11 indicate a positive relationship between CEO narcissism as a moderator in the independence of audit committee members (NARCS*ACIND) and REM through abnormal discretionary expenses. This relationship is statistically insignificant given the respective pvalue which is above the 5\% threshold. In other words, the independence of audit committee members does not moderate the relationship between CEO narcissism and REM through abnormal discretionary expenses.

\section{Conclusion and Suggestions}

The present study examined the connection between CEO narcissism and real earnings management (REM) and the role played by the independence of audit committee members in the relationship between CEO narcissism and REM. Our findings indicated no relationship between CEO narcissism and REM through abnormal cash flow and abnormal production. In addition, a significant negative relationship was found between CEO narcissism and REM through 
abnormal discretionary expenses. In other words, a more narcissistic CEO will less frequently use abnormal discretionary expenses (administrative, general, sales, and distribution expenses) for REM. Based on the above results, a narcissistic CEO is not motivated for REM through abnormal cash flow and abnormal production and abnormal discretionary expenses. The above results are inconsistent with Capalbo et al. (2017) who found a positive relationship between CEO narcissism and earning management. Furthermore, our findings showed that audit committee independence does not influence the relationship between CEO narcissism and REM through abnormal cash flow, production, and discretionary expenses. In other words, audit committee independence cannot influence the increase or decrease in the motivation of narcissist CEOs for using REM. This is inconsistent with the view that audit committee independence can improve effectiveness and productivity in a company's financial situation through controlling measures adopted by managers.

This finding is inconsistent with Kibiya et al. (2016) who found that oversight by an audit committee influences the quality of financial reporting. It seems that given the complexity involved in determining independence criteria for audit committee members in Iran, many TSE-listed companies do not closely follow these criteria and, therefore, those appointed as independent audit committee members cannot play an effective, efficient role in these committees. Thus, the Securities and Exchange Organization should define different criteria to identify the requirements for independence of audit committee members based on the economic conditions and environment in Iran.

One limitation of the present study was the lack of an accurate measure of narcissism as a personality attribute. Here we used the size of (the area of the rectangle enclosing) the CEO's signature. Researchers interested in surveys and experimental studies can use other measures like narcissistic personality inventory (NPI), content analysis of CEO's photos, and the ratio of CEO's bonuses and rewards to employees' salaries and wages. Moreover, future studies are recommended to identify how audit committee independence influences other personality attributes and other measures of financial reporting quality.

Funding: This research received no external funding. 


\section{References}

Alves, Sandra .(2011). The impact of audit committee existence and external audit on earnings management Evidence from Portugal. journal of financial reporting and accounting, 2(11): 53-82.

Amernic, J. H. and R. J. Craig, (2010). Accounting as a Facilitator of Extreme Narcissism, Journal of Business Ethics,96: 79-93.

Blue Ribbon Committee. (1999). Report and Recommendation of The Blue Ribbon Committee on Improving The Effectiveness of Corporate Audit Committee. New York Stock Exchange and National Association of Securities Dealers.

Bolo, G. \& Hasni Al-Qar, M. (2015). How Managerial Overconfidence Influences Income Smoothing in Companies Listed on the Tehran Stock Exchange. Journal of Accounting Knowledge, 21:31-53.

Bouwman, C. (2014). Managerial optimism and earnings smoothing. Journal of Banking \& Finance, 41:283-303.

Campbell, W. K., \& Foster, J. D. (2007). The Narcissistic Self: Background, an Extended Agency Model and Ongoing Controversies. New York: Psychology Press.

Capalbo, F., FRINO, A., LIM, M.Y., MOLLICA, V., and R. PALUMBO. (2017). The Impact of CEO Narcissism on Earnings Management, Journal of Accounting, Finance and Business Studies, 50:1-15.

Fakhari, H. \& Rezaei, Y. (2018). Effect of Auditing Committee on Firm's Information Environment, Management Accounting, 11(36): 63-79

Frino, A.; Lim, M. Y.; Mollica, V.; and R. Palumbo. (2015). CEO Narcissism and Earnings Management, Working Paper, http://ssrn.com/abstract $=2539555$.

Hales, J., J. L. Hobson, \& R. J. Resutek. (2011). The dark side of socially mediated rewards: How social status and narcissism affect managerial reporting. Georgia Institute of Technology. investment, and performance. Working Paper.

Ham, C., Seybert, N. and Wang, S. (2014). Narcissism is a bad sign: CEO signature size, Review of Accounting Studies, MA_r : !.

Hassan, S. U., \& Ibrahim, G. (2014). Governance attributes and real activities manipulation of listed manufacturing firms in Nigeria. International Journal of Accounting and Taxation, 2(1), 37-62. 
Hassas Yeganeh, Y., Sedighi, R. \& Hassanzadeh, F. (2017). The Relationship between Quality of Independent Auditing, Audit Committee, Earnings Management, and Cash Flow Management. Research and Science Quarterly on Accounting, Auditing, and Management Knowledge, 22:21-22.

Khajavi, S. \& Rahmani, M. (2016). Examining Impacts of CEO Narcissism on Stock Price Crash. Scientific Research Quarterly for Financial Knowledge on Securities Analysis, 37: 1-15.

Kibiya, M., Ahmad, A. \& Amran, N.(2016). Audit committee independence, financial expertise, share ownership and financial reporting quality: Further evidence from Nigeria. International Journal of Economics and Financial, 6(7):7125-131.

Kordlouei, H. \& Yousefi, V. (2017). Characteristics of Auditing Committee and Quality of Financial Statements. Business Management Quarterly, 36: 93-108

Krishnamoorthy, G., Wright, A., \& Cohen, J. (2002). Audit committee effectiveness and financial reporting quality: Implications for auditor independence. Australian Accounting Review, 12(3): 3-13.

Naderi Nayeri, N., Moeinoddin, M., \& Mirmohammadi Sadrabadi, M. (2015). Examining the Relationship between Internal Auditing, Auditing Committee, and Earnings Management in the Companies Listed on the Tehran Stock Exchange. Internal Auditors Bimonthly, 20: 20-35.

Olsen, K. J., Dworkis, K. K., \& Young, S. M. (2014). CEO narcissism and accounting: A picture of profits. Journal of Management Accounting Research, 26 (2): 243-267.

Persons, O.S. (2009). Audit committee characteristics and earlier voluntary ethics disclosure among fraud and no-fraud firms. International Journal of Disclosure and governance. 6(4): 284-297.

Rahimian, N. (2003). Future Role of Auditing Committees. Tehran: Certified Accountant: 1-5.

Salter, M. (2008). Innovation Corrupted: The Origins and Legacy of Enron's Collapse. Boston: Harvard Business School Press.

Scott Judd, J., Olsen, k.J., \& J.Stekelberg. (2017). How Do Auditors Respond to CEO Narcissism? Journal of Accounting Horizons, 31 (4): 33-52.

Soleimani Amiri, G. \& Fasihi, S. (2015). Examining the Link between Auditing Committee and Accrual and Real Earnings Managements in 
Companies Listed on the Tehran Stock Exchange. Studies in Accounting, 2(8):15-34.

Sun, J., Lan, G. and Liu, G. (2014). Independent audit committee characteristics and real earnings management. Managerial Auditing Journal, 29(2):153-172.

Tariverdd, Y. \& Ghaderi, S. (2017). Examining Effects of Financial Expertise of Audit Committee on Managerial Short-Term Visions. Experimental Studies in Financial Accounting,14(54):141-165.

Wallace, H. M. \& R. F. Baumeister (2002). The Performance of Narcissists Rises and fall with Perceived Opportunity for Glory, Journal of Personality and Social Psychology, 82(5): 819-834.

Zebedee, A.,Marquez-Illescas, G., \&Zhou, L. (2018). Does CEO Narcissism Affect Disclosure. Journal of Business Ethics, 42: 1-17.

Bibliographic information of this paper for citing:

Sardari, Roozbeh; Setayesh, Mohammad Reza; Kordlouie, Hamidreza \& Banimahd, Bahman (2021). Studying the Moderating Role of Audit Committee Independence in the Relationship between CEO Narcissism and Real Earnings Management. Iranian Journal of Finance, 5(3), 58-77.

Copyright (C 2021, Roozbeh Sardari, Mohammad Reza Setayesh, Hamidreza Kordlouie and Bahman Banimahd 